This item was submitted to Loughborough's Research Repository by the author.

Items in Figshare are protected by copyright, with all rights reserved, unless otherwise indicated.

\title{
Cooperative Learning and the affective domain
}

PLEASE CITE THE PUBLISHED VERSION

https://doi.org/10.1080/07303084.2019.1559671

PUBLISHER

Taylor \& Francis (Routledge)

VERSION

AM (Accepted Manuscript)

PUBLISHER STATEMENT

This is an Accepted Manuscript of an article published by Taylor \& Francis in Journal of Physical Education, Recreation and Dance on 15 Mar 2019, available online: https://doi.org/10.1080/07303084.2019.1559671

\section{LICENCE}

CC BY-NC-ND 4.0

\section{REPOSITORY RECORD}

Casey, Ashley, and J. Fernandez-Rio. 2019. "Cooperative Learning and the Affective Domain". figshare. https://hdl.handle.net/2134/36631. 


\section{Cooperative Learning and the affective domain}

\section{Abstract}

5 This paper seeks to give practical examples of how teachers can promote the development of

6 students' affective learning using two Cooperative Learning structures: Student Teams

7 Assessment Divisions (STAD) and Jigsaw Classroom. It also includes a taxonomy aimed to help

8 teachers value and assess their students' affective learning. The paper concludes by suggesting

9 that if Physical Education is serious in its commitment to help all students learn across the 10 different learning domains (i.e. physical, cognitive, social and affective), teachers need to be

11 more selective in their choices of pedagogical approaches. In short, they must select those

12 approaches capable of developing learning in the affective domain (e.g. Cooperative Learning

13 and structures like SDAT and Jigsaw).

\section{Introduction}

17 Physical, cognitive, social and affective learning outcomes are positioned as the key learning 18 products of Physical Education (PE) capable of promoting a physically active life (Casey \& 19 Goodyear, 2015; Fernandez-Rio, Sanz, Fernandez-Cando \& Santos, 2017). Yet, while all 20 learning domains are seen as important in research, policy and practice (United Nations

21 Educational, Scientific and Cultural Organization, 2015), the affective domain, in particular, has

22 been overlooked or under considered. This is, perhaps, because (i) it is often difficult to define

23 (Hellison, 1987), (ii) it is complex and difficult to track (Witt, 2015), and (iii) effective

24 procedures and practices to support affective learning development are less well-defined (Bailey

25 et al. 2009). In short, teaching affectively has been an enduring problem for PE.

27 Confusion has existed around affective learning and its place within school PE for several 28 decades. In the 1970s, McGee (1977) asked how affective learning might be measured. In the 29 1980s, Stoner (1982) and Mood (1982) argued "Yes!" and "No!" respectively with regards to the 30 place of affective learning in PE. Subsequently, Cutforth and Parker (1996), Gallo (2003) and 
31 Samalot-Rivera (2014) have all argued for the benefits of affective learning, and the need for

32 greater emphasis on its teaching in PE.

34 At the core of this confusion is a lack of understanding about what affective learning is and does,

35 and how to teach it. Indeed, writing nearly 30 years ago in JOPERD, Hellison (1987, p. 41) stressed that affective learning and development: "is a conceptual nightmare" and lacks

37 "instructional strategies and activity experiences" aimed at "achieving affective objectives". In

38 what remains of this paper we seek to give practical examples of how teachers can promote the development of students' affective learning.

\section{Defining Affective Learning}

43 Krathwohl, Bloom and Masia (1964, p. 7) defined the affective domain (where affective learning 44 occurs) as: "Objectives which emphasize a feeling tone, an emotion, or a degree of acceptance or 45 rejection.... internally consistent qualities of character and conscience...interests, attitudes, 46 appreciations, values, and emotional sets or biases". When considered from a modern

47 perspective, Quality PE (QPE) includes the teaching and enhancement of young people's thinking, attitudes and values (UNESCO, 2015): what we might describe as affective learning.

In models-based practice (Metzler, 2011) affective learning has been used as a broad term to 51 describe both social and psychological aspects of learning. The problem is that affective learning

52 has often been related to social learning only. Dyson (2002) argued that Cooperative Learning is

53 an effective strategy for promoting affective learning, focusing on social learning outcomes such

54 as cooperation and students' ability to encourage each other. The reason for associating affective

55 learning with social learning has perhaps emerged because affective learning also refers to

56 psychological and internal processes that are difficult to observe, assess and evaluate.

57 Furthermore, because of these difficulties, it is often measured through self-reported instruments

58 that assess student liking rather than learning (Witt, 2015).

60 There are echoes of Krathwohl et al.'s (1964) definition in SHAPE America's (2014)

61 standards. Standards 4 and 5 relate to affective learning and argue for educators to promote 
62 (i) responsible personal and social behavior, and (ii) the value of physical activity for

63 health, enjoyment, challenge, self-expression and/or social interaction. In seeking to show

64 how PE might conceptualize affective learning in practice, the following section begins to

65 look at what might be observable.

\section{Observing Affective Learning}

To support learning and development, Goodyear and Dudley (2015) argued that teachers need to be able to diagnose and evaluate students' learning. To achieve this, teachers need to focus on what students $d o$. However, what teachers should be able to observe students $d o$ regarding the

72 affective domain is less well-defined (Witt, 2015).

Two of the biggest obstacles Krathwohl et al. (1964) encountered with regards to assessing the affective domain were: (i) the inadequacy of assessment techniques, and (ii) the apparent ease with which a student might detect and exploit the understanding that some responses are rewarded while others are penalized. The taxonomy put forth by Krathwohl et al. (1964) defined affective learning as a multi-stage process of internalization through which students initially received and eventually characterize affective behaviors.

82 behavior. At the first stage (receiving/attending), students become aware of the stimuli (1.1), 83 they show willingness to receive it (1.2), before finally looking for the stimulus (1.3). At the 84 second stage (responding), students respond regularly to the stimulus (maybe because they 85 acknowledge that they need to if they are going to succeed) (2.1), they willingly accept that such 86 a response is a good thing (2.2), because it makes them feel good. At the third stage (valuing),

87 students come to hold a certain value and they wish to continue to develop their understanding of 88 the value (3.1), they actively seek out ways to exhibit it (3.2), and show an ongoing commitment 89 to act in this way. At the fourth stage (organization), students might change their code of ethics 90 (4.1), weighing future decisions against it (4.2). At the fifth and final stage (characterization by a 91 value or value complex), students "respond very consistently to value-laden situations with an 92 interrelated set of values" (Krathwohl et al., 1964, p. 35). In doing this, they might view all 
93 problems in terms of the evidence base they can see rather than prejudge (5.1), and then develop

94 a personal philosophy of life (5.2).

96 Expanding this taxonomy from a PE perspective - and drawing on the notion of Cooperative

97 Learning - at the first level individuals might become aware of the teacher's belief that

98 cooperation - through group work - is important, but might also wish to work alone. At the

99 second stage, they know that they will succeed more in the task if they cooperate, but feel that

100 they could do better on their own, even though they feel good about cooperating. At the third

101 stage, students feel that they want to work in groups, but still needs to know more about how to

102 interact cooperatively. The fourth stage sees individuals thinking cooperatively rather than

103 individually, and making decisions based on what they feel is best for the group. At the fifth and

104 final stage, decisions are made about the group's collective needs and such a philosophy (the

105 needs of many outweigh the needs of few) determine the way individuals act and responds in

106 different situations (Figure 1). Teachers could use Krathwohl et al.'s taxonomy (1964) as a rubric

107 to assess students' affective development and learning (Table 2).

108

\section{8}
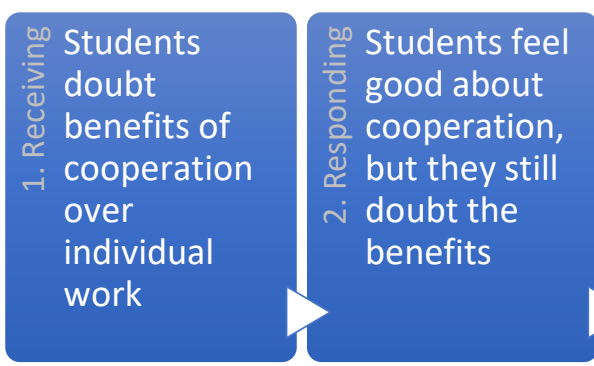

Figure 1. The affective continuum applied to Cooperative Learning.
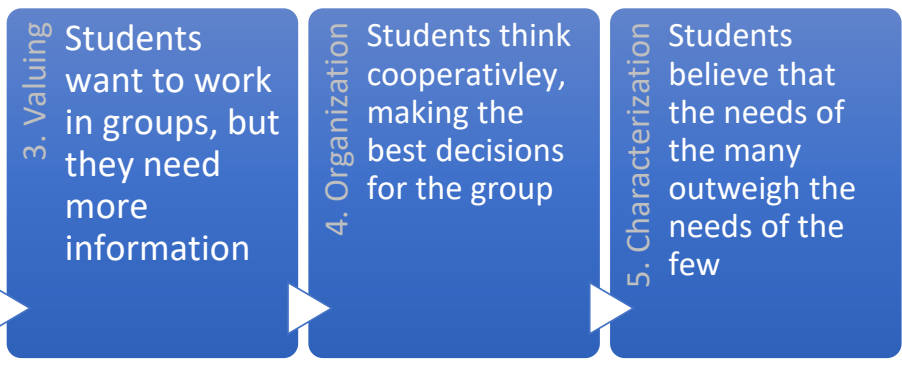

This taxonomy is used in response to an identified gap in the knowledge base about the affective domain generally (Gillies, 2016) and within Cooperative Leaning literature more specifically (Casey \& Goodyear, 2015). The following section explores how Krathwohl et al's. (1964) taxonomy and the Cooperative Learning structures of Student Teams Achievement Division (STAD) and Jigsaw Classroom could be used to promote affective learning. 
120 Cooperative Learning is not a uniform, homogenous approach to teaching and learning. Instead,

121 it has a diversified body of methods and instructional procedures that can be used to promote

122 learning in multiple domains (Sharan, 2015). Given that the intent of this paper is to focus on the

123 affective domain, it now draws on two Cooperative Learning methods (or structures) proposed

124 by Slavin (1996). They have been selected due to their theoretical foundations in psychology and

125 motivation and, therefore, a strong alignment with affective learning (Gillies, 2016).

126

127 Slavin's (2015) approach to Cooperative Learning is driven by two key components: group goals

128 and individual accountability, whereby group rewards based on the learning of individual group

129 members are embedded within these elements. The importance of group goals and individual

130 accountability is in providing students with an incentive to help each other and to encourage each

131 other to put forth maximum effort. If students value doing well as a group, and the group can

132 succeed only by ensuring that all group members have learned the material, then group members

133 will be motivated to teach each other (Slavin, 1996). Students with special needs are safely

134 integrated in class with this framework.

136 Group goals are based on the individual learning of all group members, and as a result, students

137 are individually accountable for performing to achieve the group goal (Slavin, 2015). Rewarding

138 groups based on group performance (or the sum of individual performances) helps to create

139 group cohesion (Slavin, 2015). Rewarding groups extrinsically also creates an interpersonal

140 reward structure through which group members will give or withhold social reinforcers (i.e.

141 praise, encouragement) in response to group mates' task-related efforts. To assist teachers in

142 structuring group goals, individual accountability, and group rewards, Slavin (1991) advocated

143 Cooperative Learning structures, two of which are STAD and Jigsaw.

145 Practical Example 1-STAD

147 STAD was developed with the aim of having students work in Cooperative Learning teams to

148 learn academic content (Slavin, 1996). It consists of five major components: teams, class

149 preparation, quizzes (in PE, teachers use skills/knowledge tests), improvement score and team 
150 rewards (Slavin, 1991). Table 1 describes these five components and provides examples as to 151 how a lesson might be structured within a basketball unit.

152

153 
Table 1. The five components of STAD (adapted from Slavin, 1991)

\begin{tabular}{|c|c|}
\hline Component of STAD & $\begin{array}{c}\text { Example of how to implement it in practice } \\
- \text { Basketball }\end{array}$ \\
\hline $\begin{array}{l}\text { Teams: Students are organized into } \\
\text { heterogeneous groups of four or five } \\
\text { members. In their groups, students are } \\
\text { required to practice learning tasks and help } \\
\text { each other to learn. }\end{array}$ & $\begin{array}{l}\text { A class of } 30 \text { is organised into } 6 \text { groups. Each } \\
\text { group is mixed in terms of gender, social } \\
\text { status, ethnicity, and ability. These groups can } \\
\text { be based on pre-unit assessment of ability and } \\
\text { interpersonal and small group skills. }\end{array}$ \\
\hline $\begin{array}{l}\text { Class Preparation: The class and each group } \\
\text { is presented with a group goal. The teacher } \\
\text { can provide groups with learning tasks to help } \\
\text { them achieve this goal and/or groups can } \\
\text { devise their own learning tasks to help each } \\
\text { other learn. }\end{array}$ & $\begin{array}{l}\text { A Group goal is used to help each individual } \\
\text { student improve their technique in shooting. } \\
\text { Groups are provided with resources and } \\
\text { equipment to manage their own learning and a } \\
\text { designated space on the court for their group } \\
\text { to work in. }\end{array}$ \\
\hline $\begin{array}{l}\text { Quizzes: Students within a team take } \\
\text { individual quizzes after an initial period of } \\
\text { practice. Students are not permitted to help } \\
\text { one another during the quizzes. In this way, } \\
\text { every student is individually responsible (and } \\
\text { accountable) for knowing the material. }\end{array}$ & $\begin{array}{l}\text { Each individual student performs a variety of } \\
\text { skill/knowledge tests (e.g., lay-ups, free } \\
\text { throws) and records his/her score. Then, the } \\
\text { team decides how they can help each } \\
\text { individual member improve his/her score. An } \\
\text { additional period of practice is provided. }\end{array}$ \\
\hline $\begin{array}{l}\text { Improvement scores: The quiz is repeated } \\
\text { after practice time has been provided. The } \\
\text { task is for students to obtain the greatest } \\
\text { improvement score. Groups earn points for } \\
\text { the degree to which each individual member } \\
\text { exceeds their initial score. }\end{array}$ & $\begin{array}{l}\text { Each individual student repeats the } \\
\text { skill/knowledge tests (e.g., lay-ups, free } \\
\text { throws) and records his/her score. The } \\
\text { difference between assessment } 1 \text { and } \\
\text { assessment } 2 \text { is calculated for the } \\
\text { improvement score. Each individual student's } \\
\text { score is calculated within a group's } \\
\text { improvement score (the sum of all students' } \\
\text { improvement scores). }\end{array}$ \\
\hline $\begin{array}{l}\text { Team recognition: Groups may earn } \\
\text { certificates or other rewards if their group's } \\
\text { collective improvement score exceeds certain } \\
\text { criteria or is the 'most improved group in the } \\
\text { class'. }\end{array}$ & $\begin{array}{l}\text { The teacher announces to the class the group } \\
\text { with the greatest improvement score. This } \\
\text { may be added to a leader board for all } \\
\text { invasion games events within a unit based on } \\
\text { group improvement scores. }\end{array}$ \\
\hline
\end{tabular}

156 Reported outcomes of STAD in relation to the affective domain include positive feelings of self,

157 such as self-esteem, positive student attitudes and motivation (Yeung, 2015). While these

158 outcomes are internal, Krathwohl et al.'s (1964) affective taxonomy can help us explore how

159 these types of affective learning outcomes (receiving-attending, responding, valuing, organizing,

160 and characterization) might be observable in a Cooperative Learning classroom in comparison to

161 traditional ways in which a class is conducted in PE. 
163 In using STAD, students will be able to: (i) learn to value both their own and others'

164 contributions, (ii) become increasingly self-sufficient, (iii) adapt peer teaching to suit their own 165 and others' needs, and (iv) think of ability in terms of contribution and not just performance.

166 Taking basketball as an example, PE traditionally sees students recording their efforts to score 167 from different positions on the court. Success is measured in the number of baskets and the 168 development of others is not considered important. In STAD, the group is rewarded when 169 everyone improves (see table 2).

\section{Practical Example 2 - Jigsaw Classroom}

173 The Jigsaw Classroom was developed in the early 1970s by Elliot Aronson (Aronson, Blaney,

174 Stephin, Sikes, \& Snapp, 1978) in an effort to weaken the racial cliques that had emerged in

175 schools in Austin (Texas), when previously segregated African-American, Hispanic and white 176 youngsters found themselves in the same classrooms for the first time. Such interracial tension 177 was fueled by the inherently competitive nature of schools: a competitiveness that continues to 178 exist in many schools today.

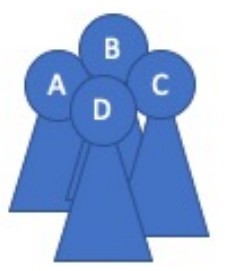

GROUP 1

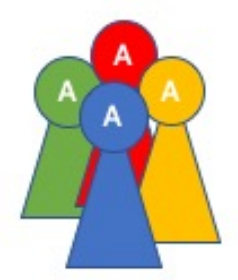

GROUP A

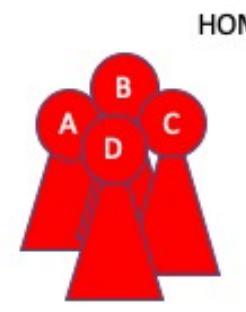

GROUP 2

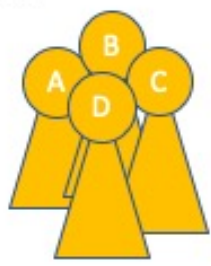

GROUP 3

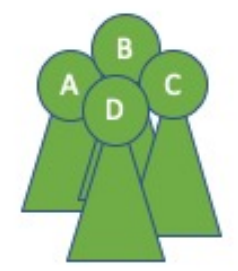

GROUP 4

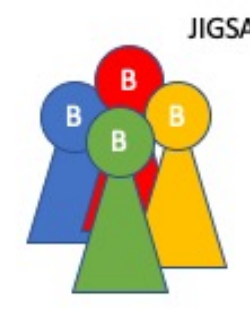

GROUP B

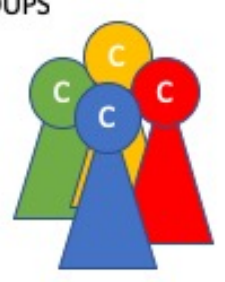

GROUP C

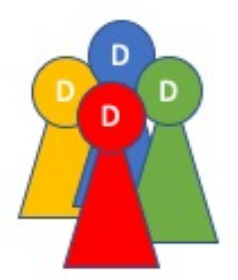

GROUP D 
182 In the Jigsaw Classroom (Figure 2) the class is split into small, heterogeneous groups called

183 Home Groups, where students spend most their time. These are the groups they learn in and

184 compete for. In each home group, however, there are experts (in Figure 2 these are labeled by

185 letters). When these students are asked to go to their Jigsaw/Expert Groups, the home groups

186 split. What remains are Jigsaw groups made up of a piece from each of the home groups. These

187 groups then become responsible for learning a specific part or body of information. This might

188 be a type of basketball shot (set shot, jump shot, layup, hook shoot) or a defensive strategy (full

189 court press, half court press, zone, man-to-man). Students become experts in an area and on

190 returning to their home groups, these expert students teach their group mates. Because Jigsaw

191 Classroom positions students as experts, they learn about the value of knowledge (whose

192 knowledge is important). Additionally, these experts can filter their knowledge and adapt

193 decisions, to consider their own strengths and weaknesses. Therefore, if an expert or a group

194 mate has a disability, activities and resources can be adapted to best suit his/her individual needs.

195 Table 2. Affective learning outcomes in traditional teaching, STAD and Jigsaw.

\begin{tabular}{|c|c|c|c|}
\hline & Traditional & STAD & Jigsaw \\
\hline $\begin{array}{l}\text { Receiving } \\
\text { (attending) }\end{array}$ & $\begin{array}{l}\text { Students receive stimuli } \\
\text { from the teacher on their } \\
\text { individual performance. } \\
\text { The focus of lessons is on } \\
\text { personal success measured } \\
\text { by "competency in motor } \\
\text { skills and movement } \\
\text { patterns... strategies and } \\
\text { tactics... and fitness" } \\
\text { (SHAPE America, 2016) }\end{array}$ & $\begin{array}{l}\text { Students receive the } \\
\text { group goal from the } \\
\text { teacher (either through } \\
\text { verbal instruction or a } \\
\text { resource) and the first } \\
\text { quiz that notifies an } \\
\text { improvement. Students } \\
\text { accept the group goal and } \\
\text { that they must engage } \\
\text { with a task using their } \\
\text { peers for support. }\end{array}$ & $\begin{array}{l}\text { Students receive } \\
\text { instruction from both the } \\
\text { teacher and their peers. } \\
\text { Eventually, they see } \\
\text { information from both as } \\
\text { being valuable and seek } \\
\text { instruction and } \\
\text { clarification from either. }\end{array}$ \\
\hline Responding & $\begin{array}{l}\text { Students consider success } \\
\text { in PE to be about how } \\
\text { their performance } \\
\text { compares to the } \\
\text { performance of their } \\
\text { peers. Performance is } \\
\text { almost always public. }\end{array}$ & $\begin{array}{l}\text { Students begin to engage } \\
\text { in promotive interactions, } \\
\text { accepting the views of } \\
\text { others to decide how they } \\
\text { can achieve the group } \\
\text { goal. Students view their } \\
\text { peers input as helpful to } \\
\text { their performance. }\end{array}$ & $\begin{array}{l}\text { Students look for } \\
\text { guidance from their group } \\
\text { and their teacher and } \\
\text { acknowledge that they } \\
\text { need to listen to both to } \\
\text { succeed. }\end{array}$ \\
\hline Valuing & $\begin{array}{l}\text { Students learn to value a } \\
\text { good performance in } \\
\text { broader terms. Effort, } \\
\text { engagement, } \\
\text { encouragement, use of } \\
\text { praise...outweigh } \\
\text { movement competency }\end{array}$ & $\begin{array}{l}\text { Students appear excited } \\
\text { by their own } \\
\text { improvement scores and } \\
\text { praise their peers. } \\
\text { Excitement might be } \\
\text { observed through students } \\
\text { organizing themselves to }\end{array}$ & $\begin{array}{l}\text { Students seek feedback } \\
\text { and instruction from their } \\
\text { peers and they are content } \\
\text { to work in this way as } \\
\text { they know they will be } \\
\text { successful. They come to } \\
\text { value the opinions and } \\
\text { ideas of others. }\end{array}$ \\
\hline
\end{tabular}




\begin{tabular}{|c|c|c|c|}
\hline & $\begin{array}{l}\text { and fitness, but success is } \\
\text { measured by performance. }\end{array}$ & $\begin{array}{l}\text { ensure they can complete } \\
\text { the task efficiently. }\end{array}$ & \\
\hline Organizing & $\begin{array}{l}\text { Students organize their } \\
\text { activities based on ability. } \\
\text { They self-select peers with } \\
\text { similar abilities to work } \\
\text { with and they pick teams } \\
\text { based on ability. Others } \\
\text { disconnect from PE } \\
\text { because they already } \\
\text { 'know' that they have } \\
\text { little to contribute. }\end{array}$ & $\begin{array}{l}\text { Individuals and groups } \\
\text { identify strategies/tasks } \\
\text { and work as a team to } \\
\text { help each other learn and } \\
\text { improve. Students may } \\
\text { modify tasks to ensure } \\
\text { that each individual can } \\
\text { have maximum } \\
\text { opportunities to enhance } \\
\text { his/her performance. }\end{array}$ & $\begin{array}{l}\text { Students balance } \\
\text { decisions and actions } \\
\text { against a combination of } \\
\text { criteria and work on the } \\
\text { advice of both teachers } \\
\text { and peers. }\end{array}$ \\
\hline Characterization & $\begin{array}{l}\text { Students are either } \\
\text { engaged or disengaged in } \\
\text { PE. They make decisions } \\
\text { about the lesson and their } \\
\text { physical activity } \\
\text { experiences before the } \\
\text { event. }\end{array}$ & $\begin{array}{l}\text { Students value input from } \\
\text { peers. They look to their } \\
\text { peers for help first and the } \\
\text { teacher second. }\end{array}$ & $\begin{array}{l}\text { Students view the world } \\
\text { cooperatively and make } \\
\text { decision based on the } \\
\text { expertise of different } \\
\text { individuals, because they } \\
\text { value them. }\end{array}$ \\
\hline
\end{tabular}

197 Again, Krathwohl et al.'s (1964) affective taxonomy can help us explore how these types of

198 affective learning outcomes (receiving-attending, responding, valuing, organizing, and

199 characterization) might be observable in a Jigsaw classroom in comparison to (i) traditional ways

200 in which a class is conducted in PE and (ii) STAD (see Table 2). The reported outcomes of

201 Jigsaw Classroom, in relation to the affective learning, suggests that: (i) it should be a joint

202 priority (alongside the major psycho-motor objectives) in Cooperative Learning lessons

203 (O’Leary, Wattison, Edwards \& Bryan, 2015), and (ii) when students are aware of both their

204 emotions and the importance of emotions they are prompted to adapt and change their behavior

205 for the benefit of the group. Just as in STAD, Jigsaw Classroom helps students to: (i) learn to

206 value both their own and others' contributions, (ii) become increasingly self-sufficient, (iii) adapt

207 peer teaching to suit their own and others' needs, and (iv) think of ability in terms of contribution

208 and not just performance. Particularly, it helps them to see that group goals, based on the

209 individual learning of all group members, are important (Slavin, 2015).

211 Conclusion

212

213 The take-home message for physical educators is: 
$214 *$ If PE is serious in its commitment to help all students learn across all domains, teachers need to

215 be cautious in their choices of pedagogical approaches, selecting those capable of developing the 216 affective domain like SDAT and Jigsaw.

217 *PE needs instruments to value and assess affective learning to know how young people's

218 feelings and attitudes change, and Krathwohl et al.'s taxonomy (1964) can help teachers do it.

219 *Teachers need to position affective learning as a central aim of their teaching to help students

220 learn to: (i) value both their own and others' contributions, (ii) become increasingly self-

221 sufficient, (iii) adapt peer teaching to suit their own and others' needs, and (iv) think of ability in

222 terms of contribution and not just performance.

223

224 References

225 Aronson, E., Blaney, N., Stephin, C., Sikes, J., \& Snapp, M. (1978). The Jigsaw Classroom.

226 Beverly Hills, CA: Sage Publishing Company.

227 Bailey, R., Armour, K., Kirk, K., Jess, M., Pickup, I., Sandford, R., \& BERA Physical Education

228 and Sport Pedagogy Special Interest Group (2009). The educational benefits claimed for

229 physical education and school sport: an academic review. Research Papers in Education,

$23024(1), 1-27$.

231 Casey, A., \& Goodyear, V. A. (2015). Can Cooperative Learning Achieve the Four Learning

232 Outcomes of Physical Education? A Review of Literature. Quest, 67(1), 56-72.

233 Cutforth, N., \& Parker, M. (1996). Promoting Affective Development in Physical Education: The

234 Value of Journal Writing. Journal of Physical Education, Recreation \& Dance, 67(7), 19-23.

235 Dudley, D. A. (2015). An observable model of physical literacy. The Physical Educator, 73(1).

236 236-260.

237 Dyson, B. (2002). 'The implementation of cooperative learning in an elementary physical

238 education program'. Journal of Teaching in Physical Education, 22(1), 69-85.

239 Fernandez-Rio, J., Sanz, N., Fernandez-Cando, J. F., \& Santos, L. (2017). Impact of a sustained

240 Cooperative Learning intervention on student motivation. Physical Education and Sport

241 Pedagogy, 22(1), 89-105. doi.10.1080/17408989.2015.1123238

242 Gallo, A. M. (2003) Assessing the Affective Domain, Journal of Physical Education, Recreation 243 \& Dance, 74:4, 44-48. 
244 Gillies, R. M. (2016). Enhancing Classroom-based Talk: Blending practice, research and 245 theory. London: Routledge.

246 Goodyear, V. A., \& Dudley, D. (2015). "I'm a Facilitator of Learning!" Understanding What

247 Teachers and Students Do Within Student-Centered Physical Education Models, Quest, 67(3), $248 \quad 274-289$. doi:10.1080/00336297.2015.1051236

249 Hellison, D. (1987). The Affective Domain in Physical Education. Journal of Physical

250 Education, Recreation \& Dance, 58(6), 41-43. doi: 10.1080/07303084.1987.10609571

251 Krathwohl, D. R., Bloom, B. S., \& Masia, B. B. (1964). Taxonomy of Educational Objectives:

252 The Classification of Educational Goals. London: Longmans, Green \& Co.

253 McGee, R. (1977) Measuring Affective Behavior in Physical Education, Journal of Physical

254 Education and Recreation, 48:9, 29-30

255 Metzler, M. (2011). Instructional models for physical education (3rd ed.). Scottsdale, AZ:

256 Holcomb Hathway.

257 Mood, D. (1982) Evaluation in the Affective Domain? No! Journal of Physical Education, 258 Recreation \& Dance, 53:2, 18-20.

259 O'Leary, N., Wattison, N., Edwards, T. \& Bryan, K. (2015). Closing the theory-practice gap:

260 Physical education students' use of jigsaw learning in a secondary school. European Physical 261 Education Review, 21(2) 176-194.

262 Samalot-Rivera, A. (2014). Role Playing in Physical Education to Teach in the Affective 263 Domain. Journal of Physical Education, Recreation \& Dance, 8(2), 41-43.

264 Society of Health and Physical Educators. (2014). National standards \& grade-level outcomes 265 for $K-12$ physical education. Champaign, IL: Human Kinetics.

266 Sharan, Y. (2015). Meaningful learning in the cooperative classroom, Education 3-13, 43(1), 83267 94. doi: $10.1080 / 03004279.2015 .961723$

268 Slavin, R.E. (1991). Cooperative learning: Theory, research and practice. Boston: Allyn and 269 Bacon.

270 Slavin, R.E. (1996) Research for the future: Research on cooperative learning and achievement:

271 What we know, what we need to know. Contemporary Educational Psychologyy, 21, 43-69.

272 Slavin, R.E. (2015). Cooperative Learning in elementary schools. Education 3-13: International

273 Journal of Primary, Elementary and Early Years Education, 43(1), 5-14. 
274 Stoner, L.J. (1982). Evaluation in the Affective Domain? YES! Journal of Physical Education, 275 Recreation \& Dance, 53:2, 16-17.

276 United Nations Education, Scientific, and Cultural Organization. (2015). Quality Physical

277 Education (QPE) Guidelines for Policy-Makers. UNESCO Publishing: Paris.

278 Witt, P.L. (2015). Pursuing and Measuring Affective Learning Objectives, Communication

279 Education, 64(4), 505-507, doi: 10.1080/03634523.2015.1064143

280 Yeung, H.C.H. (2015). Literature review on the Cooperative Learning strategy - Student Teams

281 Achievement Division (STAD). International Journal of Education, 7(1), 29-43.

282 